\title{
What Stopped the Tocks Island Dam Project: \\ The Environmental War or the War in Vietnam? \\ By Kathleen Duca
}

\section{DOI: http://dx.doi.org/10.14713/njs.v3i1.66}

The controversial damming of the Delaware River at Tocks Island would have created a 37-mile-long reservoir and recreational lake between the borders of New Jersey and Pennsylvania, flooding vast areas of beautiful land and historic buildings. In preparation, fifteen thousand people were displaced from their homes by the Army Corps of Engineers to create the Delaware Water Gap National Park and the proposed man-made lake. It took nearly forty years before the dam was finally de-authorized by Congress and the Delaware River permanently protected. The demise of the Tocks Island Dam project had always been incorrectly viewed as solely a victory for the environmental movement, but the dam was actually doomed much earlier when President Lyndon Johnson needed money to simultaneously fight the War in Vietnam and push through his Great Society legislation. Cost increases and budget cuts due to the war delayed the project long enough for it to get tangled in later environmental legislation. This paper demonstrates that a lack of funding in the late 1960s handed the growing environmental movement a fait accompli victory in the 1970s.

\section{Introduction}

The controversial damming of the Delaware River at Tocks Island, first introduced by Congress in 1962, would have created a 37-mile long reservoir for water, power, and flood control north of the Delaware Water Gap. Viewed by many to be a good idea at the time, the Tocks Island Dam would have destroyed approximately 12,000 acres of woodlands, most of the Minisink Valley, and left many farms, homes, and historic landmarks underwater. In preparation for this engineering feat, the Army Corps of Engineers displaced fifteen thousand people, wiped out 
several entire towns, large farms, historic roads and the Minisink Flats. All were either razed or abandoned. These homes and places of historic interest were doomed to become the bed of a new man-made lake that would be surrounded by a new National Park, the 72,000 acre Delaware Water Gap National Recreation Area run by the National Park Service. ${ }^{1}$

The earth and rock-filled dam was to be built at Tocks Island, a small uninhabited island in the middle of the Delaware River about five miles north of the Delaware Water Gap. It was to be 160 feet high and 3,000 feet long. It would have provided approximately 980 cubic feet of water per second to be used for hydroelectric power and as a water source. "The overriding decision to dam or not to dam the Minisink must be weighed against its natural, social and historic heritage," wrote Nancy Shukaitis, former Commissioner of the Four County Task Force on Tocks Island Dam and longtime resident of the area. ${ }^{2}$ She and countless others fought the dam project for nearly ten years before the Delaware River Basin Commission voted to terminate the project, which had an estimated price tag that had grown from $\$ 90$ to more than $\$ 400$ million. The dam project continued to rear its ugly head for several decades because it still had to be de-authorized by a foot-dragging Congress before it finally became a dead issue.

By then it was too late. Towns to be impacted, such as Bushkill and Dingmans Ferry, had become ghost towns, and Walpack's population dropped from 384 to 67. People lost their homes, their livelihoods, and their heritage. Park records show 10,000 properties, many belonging to generations of families as far back as the colonial period, were bought or condemned by the government. More than 3,000 homes occupied by 8,000 people were razed; 25 summer camps, 125 farms and more than 100 businesses, seven churches, and three schools were all demolished

\footnotetext{
${ }^{1}$ Richard C. Albert, Damming the Delaware: The Rise and Fall of Tocks Island Dam (University Park: Pennsylvania State University Press, 1987 and 2005), 1-3.

${ }^{2}$ Dennis Bertland, et al., eds., The Minisink: A Chronicle of One of America's First and Last Frontier (The Four County Task Force on the Tocks Island Dam Project, 1975), preface-vii.
} 
or abandoned. ${ }^{3}$ Since then, many historic landmarks on both the New Jersey and Pennsylvania sides of this free-flowing river that managed to survive have languished under the care of the National Park Service because of a lack of federal funding for maintenance or restoration. In 2003, the Park Service encouraged former residents, who were displaced when the park was first created, to come back to live and refurbish their own homes and pay the government rent.

The emotionally charged environmental reasons for stopping the Tocks Island Dam were a direct result of media attention focused on angry residents who joined forces with any group they hoped would help further their cause and condemn what was being done to them by the Army Corps of Engineers and, in effect, the federal government. This attention happened tangentially with the budding "Environmental Movement" that was forming in the late 1960s and early 1970s. The movement started changing pubic thinking about natural resources from protective conservationism to pro-active environmentalism, and resulted in the 1969 National Environmental Protection Act and the establishment of the Environmental Protection Agency a year later.

Before federal environmental laws were enacted and public environmental consciousness was germinating, stories emanating from Tocks Island made great press, especially for nearby New York and Philadelphia metropolitan reporters, who got to take a field trip out to Sussex or Monroe County for the day to cover an easy "hearts and flowers" story. Television cameras captured sound bites from protesting angry residents and hippie squatters, who claimed to be environmentalists. They joined ranks like sympathetic union strikers as they hugged each other and demonstrated. The atmosphere was a mixture of funeral-like mourning and tension. "It was like going to someone's wake," described attorney Donald Stieh, former president of the Walpack Historical

\footnotetext{
${ }^{3}$ Judy Peet, “A Bitterness Runs Through It,” The Star Ledger, November 23, 2003.
} 
Society, whose family lost their vacation home. "I think if a member of the Park Service had wandered onto the scene, there might have been a lynching."4

Author Richard Albert once worked for the Delaware River Basin Commission, the federal agency charged with building he dam. Following his self-proclaimed environmental epiphany, he went to work for the Delaware Riverkeeper Network, a nonprofit environmental organization that fought proposed dam projects. Before he died in 2009, Albert wrote what was the only history of the Tocks Island Dam and creation of the surrounding national park at the time. He said that like many others, he had a change of heart about saving the Delaware River, but admitted he gave the environmental movement too much credit for stopping the dam.

I offer no apology except to recognize that many subjects touched on could have been explored in greater detail. A subject for which I would like to see additional professional study is the striking parallels between Tocks Island Dam and the Vietnam War. ${ }^{5}$

How the proposed dam affected local residents and budding environmentalists is only one aspect of the history of the dam and as sad or news-worthy a story as it was, Tocks Island needed to be placed into the broader context of state and national history, especially the political and economic aspects of both. Major environmental opposition to the dam did not start until 1970, considered a late start because the environmental movement itself did not attract widespread attention until after the first Earth Day celebration was held that year and the "Save the Delaware Coalition" was organized. Ironically, the leaders of the coalition opposed the dam, but supported the creation of the recreational park area, even though it tripled the amount of land to be confiscated by the government. The environmental history of the project and the emotional effects of eminent domain on residents who lost their homes were thoroughly written about by Albert, who fifteen

\footnotetext{
${ }^{4}$ Donald Steih, Interviewed by the author, September 2010.

${ }^{5}$ Richard Albert, Interviewed by the author numerous times, last interview March 2008.
} 
years later said, "In spite of all the real and imagined environmental impacts, it can be argued that the Tocks Island Dam was a victim of cost overruns and the Vietnam War."6

The focus of this article is the history of the dam's controversial demise. The end of the Tocks Island Dam had long been celebrated as a victory for environmentalists, but this project was actually doomed much earlier when President Lyndon Johnson needed money to simultaneously fight the War in Vietnam and push through his Great Society legislation. The project had enormous cost overruns from the very beginning. As early as 1967, Time magazine criticized these costs and recommended that Congress kill the dam, calling it a lucrative "pork barrel" project that somehow managed to linger. ${ }^{7}$ Cost increases and budget cuts due to the war repeatedly delayed construction and allowed the project to get tangled in later environmental legislation. Construction of the dam never started because of a lack of funding throughout the 1960s and this delay handed the growing environmental movement an early and somewhat notable victory in the early 1970s.

\section{Dam Me a River}

Finding adequate supplies of fresh clean water had long been a problem for the more populated areas of New York City, Philadelphia, and New Jersey. New York, New Jersey, and Pennsylvania had been interested in using the nearby Delaware River as a water supply since the Colonial period. In 1923, the Delaware River Treaty Commission was legislatively created to coordinate and oversee each state's water projects. Following numerous lawsuits that eventually went to the Supreme Court, an interstate compact was adopted establishing a permanent regulatory agency, the Tri-State Delaware River Commission. On May $4^{\text {th }}, 1931$, Justice Oliver Wendell Holmes delivered the Supreme Court decision that established equitable water apportionment

\footnotetext{
${ }^{6}$ Richard Albert, "In-Tocks-icated: The Tocks Island Dam Project," Cultural Resource Management-CRM 25, no. 03 (2002), available at http://crm.cr.nps.gov/archive/25-03/25-03-3.pdf.

7 "How to Cut the U.S. Budget," Time, December 8, 1967, 38.
} 
between states and federal governance of the Delaware River for many years to come. In 1934, the Army Corps of Engineers Corps submitted the "Delaware River 308 Report," that examined the river's navigation, hydroelectric power, flood control, irrigation, water supply and water quality. The report focused primarily on the potential of building dams on the Delaware for hydropower and water supply. Of the 32 dam sites the Corps examined, they believed the site at Tocks Island showed the most promise.

States continued to conduct intermittent dam studies for the next ten years, but nothing was agreed upon. In 1949, the Delaware River Development Corporation was established in New Jersey and by 1951 the company received a Federal Power Commission Preliminary Permit to study three suggested Delaware River power dam sites, the largest to be at Tocks Island. Then, in August 1955, hurricanes Connie and Diane caused the Delaware River and its tributaries to rage and flood, claiming the lives of more than 200 people and destroying several thousand homes and businesses. As President Eisenhower arrived in Pennsylvania, the New York and Philadelphia media raced to the scene to report this natural and human disaster.

Many people mistakenly credited the Flood of 1955 as the sole motive for building Tocks Island Dam, but plans to dam the Delaware had been underway for years. After the flood, these various plans and the Army Corps of Engineers were welcomed with open arms. The proposed dam, that had an initial price tag of $\$ 70$ million, would provide flood control and water supply benefits. This proposed dam would create a 37-mile-long lake that would flood most of the Minisink Valley and be used for recreation and profitable hydro-electric power. Albert said politicians jumped on the dam bandwagon and with a flurry of resolutions ordered reviews of old studies and started new ones. A powerful interstate agency was established, the Delaware River Basin Commission (DRBC). Composed of five commissioners (the governors of New Jersey, New 
York, Pennsylvania, and Delaware and the United States Secretary of the Interior), it still exists today.

On October 23, 1962, Congress passed the Flood Control Act of 1962, which Albert said contained nearly two hundred public works projects nationwide and the "queen of its projects was the Tocks Island Dam," noting:

All the elements needed to build Tocks Island Dam had been accomplished: federal authorization, the creation of the long-sought interstate agency, and the creation of general public support for the project. None of these had been accidents."

\section{President Johnson: Conservation and the Economy of Vietnam}

What conclusions can be drawn about the evolution of the modern environmental movement by the end of the Johnson administration and what did Presidents Johnson or Kennedy do, if anything, to promote the growth of that movement during the timeframe when projects like the Tocks Island Dam were being routinely built? Was LBJ a conservationist or an environmental president? How did the proposed dam and sister national recreational park fit into his national domestic policy, especially his Great Society programs and, of course, the War in Vietnam? Had the environmental movement grown so strong and powerful nationally that it reached the White House and influenced the Johnson Administration not to build Tocks Island? Or was it just a question of economics? Did Johnson personally adopt a modern environmental philosophy rather than continued remedial conservationism? These subjects were studied by several historians who examined declassified LBJ presidential papers kept at his Presidential Library in Texas.

When the Tocks project was first authorized, it seemed to have widespread appeal. The Army Corps began buying property and evicting residents, who refused to sell. This "social engineering," as it was called, drew a lot of attention, but there was no early public focus on any

\footnotetext{
${ }^{8}$ Albert, 67.
} 
possible environmental impact of the dam until 1968, when two power companies proposed using Sunfish Pond near Tocks Island as an upper reservoir for a pumped storage electric generating facility. A grassroots campaign to save the pond drew the attention of the media and eventually the facility was relocated to another site, Yards Creek, in Blairstown, New Jersey. Once this was accomplished, construction of the dam continued to be environmentally overlooked.

However, as studies of the costs and projected benefits of the dam proliferated, early environmental concerns started to emerge while dam proponents stressed the values of efficiency, growth, and economics. This impasse caused the Tocks project to take on public significance at the end of the decade. ${ }^{9}$ Michael Frome, who helped found the Save the Delaware Coalition, wrote what later became the environmentalists' manifesto entitled, The Tocks Island Dam: A Preliminary Review, but it wasn't published until 1973. In it Frome wrote:

This is an issue of national magnitude, in which the little people who care will have their day. It marks the dawning of a new day, when the long-range effects on the environment must be measured, understood and evaluated before the shovel is turned, not after. ${ }^{10}$

In 1970, Congress ordered construction of the dam to begin as soon as it was approved by the Council on Environmental Quality (a precursor to the Environmental Protection Agency). The Corps issued its legislatively required Environmental Impact Statement in 1971, but their first brief statement was met with harsh criticism by the Council, which demanded expanded impact studies. Opposition gained momentum as politicians and the public turned against the project. Some believed the argument had turned around in a new environmentally friendly and socially conscious political climate, while others saw the need to stop the poorly-planned national park with a man-made lake and recreational facilities slated to draw crowds of ten million people

\footnotetext{
${ }^{9}$ Travis-Thompson, 36.

${ }^{10}$ Michael Frome, The Tocks Island Dam: A Preliminary Review (privately published: 1973), x.
} 
annually from the New York and Philadelphia metropolitan areas. Surrounding small rural town residents had a xenophobic fear of being over-run by "city people." The mayor of one town in Warren County told a newspaper reporter that everyone would have to buy new locks for their doors to protect themselves from the "hordes of the unwashed." 11 There was near panic in New Jersey about absorbing the costs of expanded infrastructures such as highways, hospitals, police and fire protection, and the growth of service-related businesses such as hotels, restaurants, gas stations, and convenience stores that would forever change the rural landscape of bordering states. A small number of environmental opponents were concerned about traffic, congestion, sewage and other waste disposal, seasonal drawdown of the lake, eutrophication and possible permanent damage to fisheries, yearly shad spawns, and oyster beds in the lower Delaware Bay river basin. (Eutrophication is caused when there is an excessive richness of phosphorous-rich nutrients in a lake or other body of water, frequently due to water runoff from the land, causing a dense growth of plant life and death of animal life from a lack of oxygen.)

Destruction of the last sizable free-flowing river in the east became a significant enough reason for some people like former New Jersey Governor William Cahill to openly oppose the dam in 1972. Cahill found a loop-hole to temporarily stop the project when he blocked the project's congressionally mandated cost-benefit ratio. As a member of the DRBC, Governor Brendan Byrne later voted to recommend Congress de-authorize the project, but they both fought an uphill battle because the project still had presidential and congressional support.

President Johnson's Great Society was an ambitious program that depended heavily on economic growth for funding at a time when there was none. Johnson's patriotism, political acumen, and social activism, as well as his well-known economic inexperience, notorious

\footnotetext{
${ }^{11}$ Original newspaper clip in possession of the author, without origin, date, or source included. During the author's interview with Former Gov. Brendan Byrne, he made a very similar statement.
} 
obstinacy, personal abusiveness and egotism all seemed to know no boundaries. He truly believed the United States was the world's military defender of democracy. When he became President, there were 16,000 military personnel in Vietnam and the United States helped overthrow the repressive South Vietnamese government of Ngo Dinh Diem. Fearful of both Eisenhower and Kennedy critics, Johnson was determined to continue fighting communism and "stay-the-course" in Vietnam, a decision that would later prove to be fatal to his presidency.

Domestically, Johnson was in a race to push through an enormous amount of liberal legislation aimed at improving the quality of American life and remediating the social effects of post-World War II industrial growth. Environmental historian Samuel P. Hays said modern environmentalism was slowly surfacing during this time period evidenced by a slow shift from concern about creating outdoor recreation and preserving wildlands to preserving nature, but more importantly, stopping man's encroachment on it. Hays said traditionally, conservationists justified the utilization of all natural resources if they were used efficiently and economically, as opposed to preservationists, who want to save, preserve, and protect them. Within the framework of a centralized federal bureaucracy and post-industrial laws, policy makers had focused on utilization, sound conservation practices and, of course, making money from manipulating natural resources. The modern environmental movement in the United States had its early roots in the 1960s with a more public focus on preservation, balanced naturalism, anti-pollution and public health, outdoor recreation, and the early development of studied or academic ecological sciences. The concept of “environmental protection" was often linked to the idealistic sixties' generation, and conservatives frequently and negatively associated it with other "unpopular" movements-anti-war, civil rights, and the anti-poverty movements, for starts. As it evolved and gained more wide-spread popularity, the environmental movement cut across various political and demographic boundaries. 
Uncontrolled economic growth and wasted resources began to outrage avid early environmentalists, who had formed national advocacy groups such as the Environmental Defense Fund and the Natural Resources Defense Council. The National Environmental Policy Act of 1969 signified the first active political participation in the shift from conservation to environmentalism, but Lyndon Johnson's presidency had ended during the middle of this transitional period and so did most of the funding and support for Tocks Island Dam.

Johnson's concerns for the environment were rhetorical and reactive. Interior Secretary Stewart Udall, who served under both Kennedy and Johnson, said in an oral history interview that Johnson incorporated some environmental philosophy into his Great Society legislation, including nearly three hundred conservation measures, but many of these issues were included because they were holdovers from the Kennedy administration. ${ }^{12}$ Environmental and public policy historian Martin Melosi, who recently studied newly declassified primary source documents in the LBJ Presidential Library, asked an important question: Was Johnson's new conservationism really new $?^{13}$ Johnson's idealism was mostly tempered by political pragmatism, and numerous historians and biographers have concluded he had no true personal commitment to the growing environmental movement. Hays wrote that the Johnson administration was stuck in the evolving transition from old-style conservationism to modern environmentalism. ${ }^{14}$ In his conclusions about the Johnson administration's conservation achievements, Udall said he tried to alert Johnson that trends towards total environmental awareness and quality of life were becoming the central focus of what he called, "new conservation."15

\footnotetext{
${ }^{12}$ Stewart L. Udall Oral History Interview Series, by Joe. B. Franz, LBJ Library, see http://www.lbjlib.utexas.edu/johnson/archives.hom/oralhistory.hom/UDALL/Udall03.pdf.

${ }_{13}$ Martin V. Melosi, "Lyndon Johnson and Environmental Policy," in The Johnson Years Volume Two: Vietnam, the Environment, and Science, ed. Robert A. Divine (University Press of Kansas, Lawrence, 1987), 113.

${ }^{14}$ Samuel Hays, From Conservation to Environment: Environmental Politics in the United States since World War II, Environmental Review 6 (Fall 1982): 24-27.

${ }^{15}$ Udall Interview II.
} 
Melosi said Johnson took advantage of the changing conservation movement when it served his needs, but usually his motives were insipid and he was distracted by partisan considerations and preoccupied by the Vietnam War. He unintentionally let his administration develop and propose loose environmental policies and relegated nominal national "beautification" publicity programs to his wife, Lady Byrd, that included removing billboards and junkyards from highways and national anti-littering campaigns. There was minimal federal environmental protection before Richard Nixon became President and very little environmental concern being raised by lawmakers about Congressional dam building projects like Tocks Island.

Udall wrote that he followed orders trying to reshape Johnson's Department of Interior goals and promote new legislation to protect the natural "beauty" of the land and curb pollution. "In fact, the only brake he ever felt was in the latter years of the Johnson administration when the war in Vietnam squeezed his (Udall's) budget, a victim of guns over butter," Melosi quoted historian Irving Bernstein. ${ }^{16}$ According to Bernstein, by January 1967 Udall informed the Bureau of the Budget that his department's budget shortfall for the next decade could be $\$ 2.5$ billion. Melosi further quoted Bernstein:

The overarching goal of the administration - if there was one-was to wed concern over the environment to the larger goals of the Great Society. This meant identifying with continuing congressional efforts at environmental reform or writing new legislation. These programs also fit the spirit of the Great Society and firmly grounded the "New Conservation" in traditional conservation causes. ${ }^{17}$

Udall said however that the Vietnam War and countless domestic programs such as Social Security and civil rights consumed Johnson's time and his presidency. Udall was pushed aside and they rarely spoke. There was little personal support from the president. Melosi wrote,

\footnotetext{
${ }^{16}$ Irving Bernstein, Guns or Butter: The Presidency of Lyndon Johnson (New York: Oxford University Press, 1966), 266.

${ }^{17}$ Melosi, 128-130.
} 
While environmental activity was vigorous, some programs were merely extensions of Progressive Era or New Deal resource management; others were focused more clearly on anti-pollution and other quality of life issues. Despite Udall's claim, New Conservation was not a coherent, consistent program. ${ }^{18}$

Johnson's national economic woes had a tremendous impact on funding for projects such as the Tocks Island Dam that had prohibitive cash flow problems from the start. To offset these anticipated costs Johnson proposed the establishment of twelve new national parks. These included a park in the east surrounding the Tocks Island Reservoir (lake), which he, and his accolytes, hoped would make tons of money.

\section{LBJ's Choice: Guns or Butter (and the Economic Impact on Tocks Island Dam)}

Late in his life and well after he became a celebrated author and self-proclaimed environmentalist, Stewart Udall wrote that damming the Delaware River "took on national significance by becoming a struggle that dramatized the evolution of the environmental movement in this country." ${ }^{\prime 19}$ For Udall to have placed such historic significance on the proposed dam and the key role he played in the creation of both the dam and surrounding national park is surprising given the fact that there are only a handful of documents pertaining to these projects in Udall's personal papers housed at the University of Arizona. However, his statement helps to better understand the main argument- that construction of Tocks Island Dam was not stopped simply because of growing concern for the environment or because growth of the environmental movement itself empowered national leaders to adopt anti-dam or protective policies for natural resources such as rivers. It was actually a complicated struggle that evolved over a long period of time and was absorbed by the growing environmental movement later in the 1970s and 80s, but to better understand its creation and collapse, it is necessary to again place it historically within the relevant political and economic

\footnotetext{
18 Melosi, 117-118.

${ }^{19}$ Albert, Foreword by Stewart Udall, xiii.
} 
framework of the Johnson presidency and ask why this project was so important to so many people? How did American involvement in the War in Vietnam, Johnson's domestic Great Society programs, and the economy affect the demise of Tocks Island dam?

In the introduction of the compilation, The Johnson Years, Volume Two: Vietnam, the Environment, and Science, editor Robert Divine examined historian Larry Berman's revealing assessment of Johnson's Vietnam policy, his fateful 1965 decision to fully involve the United States in ground fighting in South Vietnam, and the flawed advice Johnson received from his "Best and Brightest" advisors to reach that decision. Many historians and biographers agree the tragic and fatal misjudgment of Americanizing the Vietnam War was due to LBJ's dedication to his Great Society legislation and programs, which marginally included Tocks Island Dam. By the time the United States was fully engaged in the war, Congress had already passed 36 major pieces of Great Society legislation, but another twenty-six, including the immensely important Medicare and Civil Rights bills, were still waiting. Divine said LBJ was equally reluctant to withdraw from Vietnam or sacrifice his domestic reforms. The Vietnam War deprived LBJ's domestic programs of money. To protect his dreams of social reform, Johnson paid the enormous price of marching into a war he knew could not be won. He flatly turned down his Treasury Secretary's repeated recommendations during 1966 and 1967 that he prevail on the House Ways and Means Committee to pass a much needed new tax bill to fund the war. ${ }^{20}$ He finally caved in under much duress.

Economic historian Donald F. Kettl said funding the war and his Great Society programs was a juggling act and Johnson simply did not have the revenue to pay for it all, including expensive dam projects. Kettl recalled the 1972 Atlantic Monthly article by David Halberstam, "How the Economy Went Haywire" which noted that Presidential advisor Bill Moyers called the

\footnotetext{
${ }^{20}$ Bator, 14.
} 
delay in seeking the tax increase, "the single most devastating decision in the Johnson administration that helped to undercut the base of his internal support ... he lost control of the administration, lost control of events," said Moyers. The three-year delay in establishing a tax increase to help pay for the war fueled unprecedented inflation. ${ }^{21}$ Johnson's national economic woes had a tremendous trickle down impact on funding for projects such as the Tocks Island Dam that had prohibitive cash flow problems to begin with. Albert concluded:

The impact of the Vietnam War on Tocks funding was almost immediate. Just as the dam was being funded, domestic spending programs were being cut. Inflation, heated by the budget deficit began rising. Externally, the project was competing for dollars that were being sent to fight Communism in Southeast Asia. During the second half of the 1960s there just wasn't enough money in the federal treasury to build grand dam projects in the Minisink Valley and also wage war."22

So how did a marginal program like the Tocks Island Dam and surrounding National Recreation Area manage to escape the federal budget chopping block? While many of Johnson's other domestic programs were sacrificed, biographers agree Johnson egotistically refused to relinquish many of his domestic projects. He begrudgingly allowed them to suffer severe budget cuts with the hope he would eventually find the funding to later resurrect them. Secretary Udall suggested another explanation might come from a close examination of who supported building dams like Tocks Island and why. Udall concluded:

Most Congressmen under the old pork barrel system, regarded this (Tocks Island Dam) as a beneficial thing, something good for the country and they'd go home with their projects and feel that they brought the bacon home for the people ... but increasingly these activities came under question. Conservationists did not want dams in certain areas. So, we began confrontations with them. Congress began to put little amendments on bills giving Interior a right to review certain things. The (Army) Corps didn't like any of this. Their Congressmen didn't either. . . I found myself as the decade wore on, increasingly questioning myself (and) some of their major dam building projects that at the beginning of the 1960s had appeared to be

\footnotetext{
${ }^{21}$ Donald F. Kettl, "The Economic Education of Lyndon Johnson: Guns, Butter, and Taxes, ” in The Johnson Years, Volume Two: Vietnam, the Environment, and Science, edited by Robert A. Divine (Lawrence: University of Kansas Press, 1987), 54.

${ }^{22}$ Albert, 75-79.
} 
a sort of sacred cow... usually, no one was supposed to have a say about it except the concerned Congressmen, the people in a given state and the Corps . . . but it wasn't easy and you had to fight them every step of the way. ${ }^{23}$

\section{The Delaware National Pork Barrel Park?}

Municipal utilities, unions, private businesses, and investors all stood to make a good deal of money from the new dammed lake and surrounding national park through real estate brokering, building and construction, or owning businesses that would support the huge crowds of anticipated park tourists. These eager entrepreneurs became the biggest supporters of Tocks Island Dam, not because they supported dam building, but because they wanted to capitalize on the profits from a proposed enormous man-made lake to be surrounded by one of the biggest national parks in the most heavily populated part of the country. The federal government was providing them an open opportunity to make money at tax payers' expense and they mustered all the political support they could get.

Udall was just as interested in protecting the special interests of certain politicians associated with Tocks Island, who could help him get other national legislation, especially the Wilderness Bill, passed and win ongoing battles in western states particularly against his archnemesis Congressman Wayne Aspinall, the powerful Chair of the House Interior and Insular Affairs Committee, who was a stubborn advocate of resource development and avid protector of the western mining industry. Udall said he called in political chips.

The device I used was to work with the (Interior and Insular Affairs) committee members who were for it (the Wilderness Bill, introduced by Hubert Humphry in 1962.) And particularly Congressman Saylor of Pennsylvania became one of the outstanding advocates. It was a kind of horse trading. I would work with Saylor and others on the committee and they'd keep nagging at him (Aspinall). ${ }^{24}$

\footnotetext{
${ }^{23}$ Udall Interview V, 10-11.

${ }^{24}$ Udall Interview $\mathrm{V}, 8$.
} 
During his battles with Aspinall and debates over the future of public lands, Udall had formed an alliance with Congressman John Saylor, $22^{\text {nd }}$ District of Pennsylvania, who sat on the Interior and Insular Affairs and Veterans Committees. Saylor and Udall had a lot of common interests, including Tocks Island Dam and the National Park. Evidence of massive lobbying efforts are contained in Saylor's personal papers on Tocks Island Dam and newspaper clips housed at the Indiana University of Pennsylvania. These papers contained hundreds of letters of correspondence concerning Tocks Island mostly from members of the Water Resources Association of the Delaware River Basin (WRA-DRB or simply WRA), an organization that claimed to represent more than 500 supporters of the dam and the national recreational park, and its off-shoot organization the Tocks Island Regional Advisory Council.

The WRA was composed of mostly private businessmen, water, power and utility, and sewage companies, and government and municipal agencies. There were no environmental interests represented in this organization. ${ }^{25}$ Leaders and members of the WRA emphatically endorsed the dam and the park and conducted expensive media campaigns to garner more support. They made a documentary film used to unify lobbying efforts as they diligently worked to persuade Congress to act on the dam's construction. ${ }^{26}$ The WRA, headed by Frank Dressler, represented many dam supporting organizations and people who stood to benefit from the Tocks project including the vacation resort industry, unions and other labor groups, builders, land speculators, private utilities, economic development organizations and members of various Chambers of Commerce, and of course, land speculators. He urgently and repeatedly lobbied Saylor and other representatives to have the recreation area created as expeditiously as possible. ${ }^{27}$

\footnotetext{
${ }^{25}$ Water Resources Association of the Delaware River Basin, see http://www.wradrb.org/.

${ }^{26}$ Albert, 82.

${ }^{27}$ Letter from Frank Dressler to New Jersey Congressman William B. Widnall, January 25, 1965, Papers of Rep. John Saylor (Indiana University of Pennsylvania: Special Collections and Archives). Saylor was copied on this letter.
} 
Because Tocks was “on hold” due to the War in Vietnam, it gave property owners and real estate investors time to speculate on doomed land and escalate the prices of property everyone knew the government needed to buy to build the dam and the park. "The price for land was the major dollar problem for the National Park Service," wrote Albert. ${ }^{28}$ The agency had been given only $\$ 37.5$ million to purchase 47,675 acres of land and the price kept escalating. The price of real estate, both inside and on the outskirts of the site doubled and sometimes tripled as early as 1965 , according to local news articles. An ad placed in the Wall Street Journal by Lewis and Haring Realtors in Newton, New Jersey offered 625 choice acres on the Delaware River for sale. "This offering is particularly attractive because of its involvement in the scheduled establishment of a thirty-seven mile lake and the National Park surrounding the lake-already approved by Congress." New Jersey claimed the property had "built-in value for any negotiations with the government - condemnation is scheduled within three to four years." ${ }^{29}$ The Newark Sunday News ran ads offering summer homes for only $\$ 3,495$ or lots for $\$ 279$, requiring a down payment of only \$15 and \$5 payments per month at Blue Mountain Lakes, within the boundaries of the recreation area. "Persons purchasing land now may expect to earn a profit between their purchase price and the fair market value which the Government must pay at the time of acquisition," the ad proclaimed. $^{30}$

There were significant "back-room” connections between Dressler, Saylor, and Udall. In a letter dated September 14, 1966, Dressler asked Saylor to keep Udall to his promise of providing $\$ 15$ million in federal funding that year for land acquisition. In another of his many letters, Dressler profusely thanked Saylor for everything he had done to facilitate the authorization and funding of

\footnotetext{
${ }^{28}$ Albert, 86.

${ }^{29}$ Wall Street Journal, August 19, 1966.

${ }^{30}$ Newark Sunday News, August 28, 1966.
} 
Tocks Island Dam and the Delaware Water Gap National Recreation Area. "We of course look forward to working with you until the day these vitally important projects have been completely developed," wrote Dressler.

To be clear, the dam and the national park represented two different and separate projects, two separate acts of legislation, and two funding revenue streams with attached budgets that needed congressionally approved appropriations. Tocks Island National Recreation Area legislation was introduced by Saylor, who at the time was the ranking minority leader of the House Interior Committee. The bill, signed by Johnson in 1965, gave the Secretary of Interior $\$ 37.4$ million to acquire an additional 47,675 acres of land and $\$ 18.2$ million for the park's proposed recreational facilities. Albert called it a "Central Park for Megalopolis," referring to a 1966 Master Plan developed by Peter DeGelleke.

The thirty-one largest sites focused on reservoir recreation...planners envisioned something on the order of 11,000 picnic tables, 6,500 camp sites, 135 boat launches, 1,860 boat docks, 33,000 parking spaces; 15 food service areas and beaches for 66,000 bathers. ${ }^{31}$

If you didn't want to go to the beach, Albert wrote other planned recreation included: boat rentals; miles of hiking and bicycle trails; horseback riding; picnicking; hunting; fishing; sailing; motor boating; canoeing; rock climbing; nature centers; playgrounds; ballfields and more. All of this would serve an expected 150,000 visitors per day, which would have made it, "the busiest park in the National Park System.,"32

Even after LBJ signed the bill, Dressler wrote to Udall urging him to begin the project as rapidly as possible and again, he copied Saylor. Udall clearly understood the need for "pork barrel legislation" and was aware of the "pork barrel" interest in Tocks and the local constituents who stood to make a good deal of money from this outdoor "Disneyland" project situated within 100

\footnotetext{
${ }^{31}$ Albert, 86.

${ }^{32}$ Albert, 86.
} 
miles of the New York and Philadelphia metropolitan areas. From this perspective, the Tocks Island Dam and Delaware National Park were hardly environmental controversies at all. The real fight (over a man-made lake with a national park protecting it) was between those who stood to benefit from the millions of people expected to visit it annually and local residents, who did not want to lose their homes or see this pristine area become over-developed. Environmental concerns were not important.

The results of this public notoriety during a time of serious inflation and budget crisis spending during the Vietnam War resulted in two scathing full page editorials in Time magazine that specifically recommended cutting expenditures for unnecessary projects such as the Tocks Island Dam. The first anonymous editorial was published August 4, 1967. Entitled "Congress: Where Charity Begins" criticized the House for recently passing a \$4.6 billion public works appropriation bill. " $\$ 2$ billion of which is pork...including such frills as the Delaware River-Tocks Island reservoir and recreational program at the New Jersey, New York, and Pennsylvania border, which was supposed to cost $\$ 90.4$ million but has since grown to a tidy little \$198 million affair."33 The second article contained derisive suggestions on how Washington should cut federal spending on unnecessary programs such as Tocks Island Dam. ${ }^{34}$ Albert wrote:

The rich aroma of pork converts even the most ardent budget cutters into big spenders. High on Time (magazine's) recommended hit list for funding cuts was the non-essential and increasingly expensive Delaware River-Tocks Park." 35

\section{Nix on Tocks: The Environmental Demise of the Dam? The 1970s and Beyond}

As the turbulent decade of the sixties came to a close and President Johnson refused to run for another term, Richard M. Nixon became president backed by the populist "silent majority"

\footnotetext{
33 "Congress: Where Charity Begins," Time, August 4, 1967, 23.

34 "How to Cut the US Budget," Time, December 8, 1967, 46.

${ }^{35}$ Albert, 77.
} 
who supported his futile attempts to re-establish domestic tranquility. The War in Vietnam dragged on, the economy continued to suffer, and no contracts had been forged for the construction of Tocks Island Dam. New regulatory environmental legislation, the National Environmental Policy Act of 1970, required the Army Corps of Engineers to now furnish an environmental impact statement on the dormant dam project. Those who strongly felt this impact statement led to the "environmental demise" of Tocks Island may not have been aware that the key players, members of the Delaware River Basin Commission, who voted against the dam in 1975, did not necessarily do so for environmental reasons. It was really an issue of money.

Significant environmental opposition to the dam did not start until after 1970, mostly because the recreation area appealed to many traditional dam proponents and environmental causes in general had not gained widespread interest until after the first Earth Day in April of that year. Of course during the following decade every possible environmental objection to the dam was subsequently raised, but despite these real or imagined later environmental impacts, the dam remained a victim of the Vietnam War, cost overruns, ${ }^{36}$ and poor planning. Prices for land acquisition, geological site problems, cemetery and grave re-location and other costs had escalated or were unanticipated. The biggest opponents remained the doomed victims of eminent domain, or as Albert called it, "social engineering."

\section{Chickens and Traffic Jam the Dam}

As the seventies progressed, the two biggest concerns about building the dam escalated. They were the diminished cost/income benefit and newly exposed adverse environmental impacts

\footnotetext{
36 The original $1962 \$ 90$ million cost estimate turned out to be extremely underestimated. Changes in the dam's design because of geological footing problems added an additional \$16 million by 1965 and the need for protective works in the upper part of the reservoir pool added another $\$ 14$ million. Another $\$ 12$ million was added to relocate cemeteries, schools, highways and power lines and an additional $\$ 15$ million was needed for land acquisition. $\$ 8$ million was added for wildlife migration measures. By July 1967 the estimated cost of the dam was \$198 million and these cost estimates continued to rise steadily until it reached more than \$400 million in 1972.
} 
of the project. In March 1968 a report conducted by the House Public Works Committee found the cost benefit ratio of the lake and park had fallen below the mandated 1 to 4 ratio. According to Albert, Senator Allen Ellander (D-La) chairman of the Senate Subcommittee on Public Works and House Public Works chairman, Congressman Michael Kirwan (D-Ohio) determined recreational and water supply benefits had been grossly over-estimated. "Even Congress, which usually favored expensive pork-barrel projects, was beginning to wonder if the country could afford a costly project like Tocks," Albert wrote. “Tocks Island Dam was beginning to get a reputation as a bottomless pit for federal appropriations." 37 A later report conducted by the Environmental Defense Fund in February 1972 again disputed the Army Corps calculations, calling them "misleading and overestimated." "38

Also in 1972, New Jersey Governor William Cahill, a voting member of the DRBC, reevaluated his support and asked a team at the state's newly created Department of Environmental Protection, headed by Commissioner Richard J. Sullivan and Assistant Thomas M. O’Neill, to again review the costs and benefits and environmental impact the project would have on New Jersey. According to O'Neil, Cahill tasked them to focus on three critical areas: the impact on land use and necessary supplemental infrastructure facilities; the cost, appropriateness, and environmental impact of proposed regional sewage facilities; and the highway system that would be needed to serve the estimated 10.5 million annual visitors. Cahill also questioned the benefits of the dam for water supply and flood control and demanded a set of conditions be met before New Jersey would agree to move ahead with the project, the most adverse being his insistence that the

\footnotetext{
${ }^{37}$ Albert, 77.

${ }^{38}$ H. Doc 522,1:99; see also “Tocks Island Lake, Pennsylvania, New Jersey and New York, Pertinent Data,” Loose Papers, Box 503 and Box 5276 Administrative Records, US Army Corps of Engineers, Philadelphia District, Philadelphia, PA.
} 
number of annual visitors be reduced to no more than four million a year. ${ }^{39}$ Cahill had found the most significant loophole to stymie the project and protect his state. According to O’Neill,

His reaction was this project was not going to fly. This put the first substantial roadblock in the way of the dam without any real friction. What he really did was make it impossible to comply with his requests. If you put a ceiling of four million park visitors a year on it, they (the Army Corps) would not be able to get a positive cost benefit analysis. The Corps could no longer justify it, not on environmental grounds and they could not justify it on economic grounds. They would not be able to get over the Congressional hurdle of having a positive cost benefit ratio. ${ }^{40}$

Engineering studies revealed that during times of drawdown, (partial draining of the reservoir during times of low water flow or drought) vast unsightly mudflats would grow along the lakeshore. Numerous environmental impact studies indicated algae fed by phosphorus-rich storm water runoff from nearby New York State chicken and dairy farms into the stagnant reservoir water would cause it to become a eutrophic gigantic cesspool unfit for recreation, which was supposed to make up 51 percent of the projects' congressionally mandated income benefit. New York State refused to absorb the cost of building expensive treatment facilities to control this agricultural water pollution.

In 1970 the Council on Environmental Quality ${ }^{41}$ demanded the Corps address specific issues that included: water quality and potential eutrophication; alternatives to the dam; impacts on fish habitats in the Delaware; secondary costs and benefits; and the impacts of seasonal

\footnotetext{
39 "Statement Concerning the Tocks Island Dam" by William T. Cahill, Governor of New Jersey, given during the annual meeting of the Delaware River Basin Commission, May 10, 1972. Document copy given the author by Thomas O'Neill, former Assistant Director of the NJ DEP.

${ }^{40}$ Interview with Thomas O'Neill (former Executive Assistant and Chief of Staff to the Commissioner of the New Jersey Department of Environmental Protection under both NJ Governors, William Cahill and Brendan Byrne) by the author, March 1, 2011.

${ }^{41}$ The Council on Environmental Quality (CEQ) coordinates Federal environmental efforts and works closely with agencies and other White House offices in the development of environmental policies and initiatives. CEQ was established within the Executive Office of the President by Congress as part of the National Environmental Policy Act of 1969 (NEPA) and additional responsibilities were provided by the Environmental Quality Improvement Act of 1970. See https://www.whitehouse.gov/administration/eop/ceq/about.
} 
fluctuations in the reservoir's water levels. In October 1971, the Corps responded with its Impact Statement that concluded eventual eutrophication of the reservoir was likely because of sewage and animal waste water pollution from upstream farms in New York. This environmental impact report identified many other possible adverse impacts from the dam that included adverse impacts on the fish population; exposure of mudflats during reservoir drawdowns; loss of agricultural lands and historic landmarks; the loss of historic Old Mine Road and the Pahaquarry Copper Mine; loss of wildlife and natural habitat and surprisingly, the hardships imposed on current residents about to lose their homes. The Corps had been ready to advertise for construction bids, but these issues jeopardized the Corps' continued funding and stopped them from moving ahead. In June of 1973, both the House and the Senate approved a $\$ 14.8$ million appropriation, but stipulated it was to be used for property acquisition only and not construction.

\section{Governor Brendan Byrne's White Paper}

On August 28, 1974 Congress appropriated \$1.5 million for a new study of the Tocks Island Dam project, but instead of allowing the Department of Environmental Protection to conduct the study, it gave the project to the pro-dam Army Corps of Engineers. This immediately raised concerns that the new study would be biased if managed by the Corps. Instead, two neutral New York City consulting firms were given the contract, engineers URS/Madigan-Praeger and the architectural firm Conklin and Rossant. Their six-volume final report resulted in a stalemate with both sides declaring victory. It concluded that the project was the most cost-effective means to achieve the purposes of flood control, water supply, recreation, and hydroelectric development in the region, however, they believed recreation would be adversely affected by eutrophication of the man-made lake. 
In 1974, Brendan Byrne became governor of New Jersey and appointed David Bardin Commissioner of the NJ DEP. Like Cahill, the conflicted Governor Byrne asked for a new and private independent study of the dam project be conducted by Thomas O'Neill and Dr. Glenn Paulson, both assistant DEP Commissioners. They began a lengthy new study of Tocks Island Dam and the recreation area they called "The White Paper," which was never publicly released. O'Neill said once given their findings, Byrne's overriding concern was the cost effectiveness of building the dam. "It was the politically salient concern he had," said O'Neill. "It was not an environmental concern, it's a money concern and everybody can understand that." ${ }^{22}$ O'Neill said he thought Byrne made a gut decision using the White Paper to support it. Former Governor Byrne said he voted against building Tocks Island Dam in the mid-1970s (which ultimately led to its deauthorization during the Carter administration), predominantly because of the anticipated costs to New Jersey. Paulson and O'Neill, who wrote "The White Paper," concluded that New Jersey had adequate alternative water supplies and "the recreational values basically they (the Army Corps) asserted were a sham,” said Paulson. During an interview, Governor Byrne recalled:

The initial reasons for building the dam all seemed very logical, (but) there was a lot of negative press and squatters protesting. It was more of a social issue. I did not care about the dam one way or other. I knew there were people, who were concerned about the issue of water supply, but mostly it was just getting a lot of negative media coverage and I had the impression that nobody had thought through all of the possible effects. They didn't know how they were going to deal with the eutrophication and I could see scum. ${ }^{43}$

The Army Corps finally recommended Congress de-authorize the dam in September 1975, and transfer the land it had acquired for the dam project to the National Park Service. Congress failed to pass a de-authorization bill for several more years and the possibility of a dam being built

\footnotetext{
${ }^{42}$ Interview with Thomas O'Neill (former Executive Assistant and Chief of Staff to the Commissioner of the New Jersey Department of Environmental Protection under both New Jersey Governors Cahill and Byrne) by the author, March 1, 2011.

${ }^{43}$ Interview with Former NJ Governor Brendan Byrne by the author, September 16, 2010.
} 
still lingered. Environmental groups and opponents then aimed to ensure that no construction ever occurred by pushing Congress to designate the Middle Delaware River as a wild and scenic river. The Wild and Scenic Rivers Act, passed by Congress in 1968, declared that rivers with "outstandingly remarkable scenic, recreational, geologic, fish and wildlife, historic, cultural, or other similar values" would be "preserved in free-flowing condition." 44 President Jimmy Carter signed the National Parks and Recreation Act of 1978, adding a substantial part of the Delaware River to the National Wild and Scenic Rivers System. The passage of this legislation protected the Delaware River and finally blocked Tocks Island Dam. This protective designation was a victory that can truly be attributed to the modern environmental movement.

Congress voted to de-authorize the project in July 1992, but with the provision that the dam be retained in the DRBC's Comprehensive Plan and reviewed again after the year 2002, when it was finally de-authorized with no provision for future reviews. In November 2000, sixty-five miles of the lower Delaware River were added to the National Wild and Scenic Rivers System designation, making seventy-five percent of the non-tidal river between New York State and Trenton untouchable. The remaining twenty-five percent is too small to build a dam or create a reservoir.

\section{Conclusion}

Rivers have long been a battleground between those who want to keep them free flowing and natural and those who want to harness water to create improvements. There are more than 75,000 dams in the United States that affect every major river outside Alaska but one, the Salmon River in Idaho. In addition to 400 large dams used to control floods, as of 1965, these dams created more than 26,000 miles of channeled waterways for shipping, 58,000 million acres of irrigated

\footnotetext{
${ }^{44}$ Albert, 150.
} 
land, and the generation of 30 million kilowatts of hydroelectricity. While these improvements have been deemed significantly beneficial and essential, river conservationists have claimed the most complete and permanent destruction of a river is by a dam. Environmental studies have shown when a dam stops the river's current, the landscape is flooded, the chemistry and temperature of the water changes, and deep water blocks sunlight and stops the growth of bacteria and other food chain nutrients.

There has only been only one very comprehensive book written about the history of Tocks Island, but the author, Richard Albert, was undoubtedly an anti-dam environmentalist and wrote it with that slant. The end of the Tocks Island Dam project has always been viewed as a victory for the growing environmental movement, but there was more to the story and it was simply a matter of money and time. Tocks Island Dam became irrevocably log-jammed during the Carter Administration, but its demise really happened earlier when President Johnson needed funding to simultaneously fight the War in Vietnam and push through his key domestic programs. "Guns or Butter" handed the growing environmental movement this later victory. Budget cuts for smaller projects and programs delayed Tocks Island long enough for it to later become economically and environmentally unfeasible, especially after the enactment of the National Environmental Protection Act. In studying the history of Tocks Island Dam, the possibility of this argument had to be taken into account. Albert concluded his book by saying it was the War in Vietnam that was the major reason for the demise of the Tocks Island Dam:

The idea was born in an era when an undammed river was considered a wasted resource and river taming was considered good water conservation. It was the Vietnam War, however, that kept the project from being built. In many respects, Tocks Island was the Vietnam War of the Delaware Valley. In 1975 both the dam and the war collapsed from weakened political support and rising public pressure." 45

\footnotetext{
${ }^{45}$ Albert, 175.
} 
Did the environmental movement really cause the demise of Tocks Island Dam and did environmentalists successfully stop other dams from being built elsewhere? In the late 1990s, within only a few years of the de-authorization of Tocks Island Dam, more than 450 new dam projects were authorized for construction by the Army Corps of Engineers. By all means, this project should have been one of many cut by the Johnson administration due to a lack of funding. Construction was never started and there was no significant national reason to keep the dam except for the tremendous lobbying efforts of those who had "pork barrel" economic interests in the project such as the WRA/DRB or certain politicians.

Was the demise of the Tocks Island Dam project really a "win" for the environmental movement? At first glance and from a present day environmental history outlook, the answer would be yes because no dam was built and the river was preserved. However, there were actually two finales to the Tocks Island Dam project and they needed to be chronologically separated and examined. The first demise of the dam was between 1965 and 1970, when federal funding was diverted from the project to pay for the War in Vietnam and poor planning resulted in diminished cost benefits. This happened before any significant environmental movement had taken up the cause to stop the dam's construction. The second, largely environmental, effort dragged on for years before legislation was finally enacted to stop the dam once and for all, but these environmental efforts were "au fait accompli."

Viewed historically, the second demise, later in the 1970s, considered the "environmental win," was largely after-the-fact, and a controversy culturally created by the media, who clamored around the victims of eminent domain and the coalitions they formed with well-intentioned wilderness conservationists, hippie squatters, and some people who were likely legitimate modern environmentalists. Regardless of their environmental or altruistic values and motives, the people 
who were losing their homes were not as concerned about displacing shad and oysters as they were about losing the roofs over their heads. These were the people who officially spear-headed the controversy and were repeatedly interviewed by the press or caught on camera angrily demonstrating with a mixture of concerned citizens, but Tocks was fundamentally a dead issue long before this second group of "environmental" supporters took credit for officially halting the project.

The second and later environmental controversy that continued until 2002 may have served as an ecological epiphany for some, but in the 1960s there were still very few sympathetic legislators capable of enacting laws to protect the environment and actually not much widespread public support for local environmental causes. Decision makers did not consider "the environment." They were conservationists, born of the Teddy Roosevelt old school of preserving natural resources as just that, resources to be used for man's benefit. Stuart Udall, Secretary of the Department of the Interior under both Presidents Kennedy and Johnson was one of the biggest supporters of building dams in the 1960s and certainly neither of his bosses were too concerned with environmental issues. Johnson's administration managed to pass legislation to stop the further pollution of air and water, but these were not proactive, protective measures--they were reactive, crisis management issues that had found their way onto his plate, which was already full of social discontent and rhetoric about the War in Vietnam, the Civil Rights movement, the crushing budget deficit, and inflation. Liberals, who were considered the earliest proponents of the environmental movement, were viewed to be the same people giving Johnson a headache by protesting just about everything.

Emerging environmental administrators like O'Neill and Paulson had to fight people within the newly created New Jersey DEP, who thought the dam was the only way to meet New Jersey's 
water supply needs, an idea which turned out to be completely without merit once the state and the DRBC conducted new studies and later produced a new master water plan. Conscientious people began to conserve water much in the same way it became the norm to recycle. Environmental values were still intangible and had not yet fully become articulated. Early decision makers, who first put the dam into motion, did not have the benefit of environmental impact data or scientific forecasting. The construction of the Erie Canal or the Transcontinental Railroad in the 1860s caused devastating environmental impacts, but no one thought about the endangered buffalo or the possibility of land choking dust bowls. Tocks Island Dam was frozen in a half century of environmental transition that was provisional, unclear, and tentative at best.

Luckily, the long term goals of the environmental movement gained strength and the majority of Americans came to realize that it is wrong to perpetuate urban/suburban sprawl or to cut down trees without replanting new ones or to kill animals close to extinction. The planet has grown smaller and as people have become more aware of man's place in it and the damage being caused by carelessness and greed, the environmental movement has become mainstream and accepted. At the time of Tocks Island we might have been on the way, but we still had a long way to go.

"In retrospect, there is no doubt that the same territory would have lost its virgin natural resources had this aggressive land grab not taken place" said Nancy Shukaitis, who is now in her mid-80s. "If the Department of Interior holds fast to its federal mandate and all the laws governing National Parks prevail, these 72,000 acres will always be the pride of America, along with more than 200 other federal park treasures. Those of us who were left to relocate to places away from 
and outside of the park still have our grand memories of the 'good life' when traffic was nil, there was an absence of noise, real tranquility existed and paddling on a river was close to heaven." ${ }^{46}$

\section{TOCKS ISLAND DAM PROJECT TIMELINE}

1783 New Jersey and Pennsylvania sign The Anti-Dam Treaty of 1783 and determine river island ownership. The Delaware River is considered a common highway and no dams are allowed.

1823 Lehigh Canal opens and others follow supporting Industrial Revolution demands for coal. The population explodes and water supply demands increase dramatically.

1903 The Delaware River Development Company is incorporated in New Jersey and creates the first plans for a dam on the Delaware River.

1906 New York builds New Croton Dam on the Delaware's headwaters. 1907-1928 the Catskill System is built to supply New York City.

1923 The lumber rafting industry has ended on the river.

1924 The Pennsylvania Water and Power Resources Board proposed a dam at Walpack Bend.

1925 The Delaware River Treaty (Tri-State) Commission was created by New Jersey, New York and Pennsylvania to equally share the river's water and maintain minimum flow.

1929 New Jersey sues New York and New York City over Delaware River water rights.

1931 The US Supreme Court rules on the Delaware River Case. Justice Oliver Wendell Holmes affirmed each state in the Delaware River Basin has a right to a fair share of the river's water.

1954 The French Army was defeated at Dien Bien Phu. The United States sends advisors to Vietnam.

1955 Pennsylvania began studying a Delaware River dam site at Walpack.

Two devastating hurricanes caused record floods along the Delaware in August.

1956 The US Army Corps begins a major study of the Delaware River basin.

The Delaware River Basin Advisory Committee is created.

1957 The Army Corps picks Tocks Island as their preferred site for a dam on the Delaware.

1959 The Delaware River Basin Compact was adopted by four key states.

${ }^{46}$ Interview with Nancy Shukaitis by the author, February 23, 2011. 
1960 Tocks Island Dam and upper pumped water storage plans at Yards Creek were finalized.

1961 President Kennedy signed the Delaware River Basin Compact. Power companies purchase land including Sunfish Pond from New Jersey and plans are made to use it for pumped storage to generate electricity.

1962 Congress passed the Flood Control Act of 1962 (P.L. 87-874) that contained nearly 200 national public works projects, including the Delaware River Basin. There were 11,000 American troops in Viet Nam.

1963 Estimated Tocks Island Dam project costs increased from an additional \$16 million from $\$ 90$ million.

1965 To Bills authorizing both the Delaware Water Gap National Recreation Area and the construction of the Tocks Island Dam were finally authorized by Congress. The dam would have created a recreational lake surrounded by a National Park. Water and recreation are measured into a cost-benefit ratio.

There were 150,000 American troops in Viet Nam.

1966 The Army Corps received \$1.2 million funding for Tocks but the project start was way behind. President Johnson starts facing funding shortages because of the War in Viet Nam. The Lenni Lenape League was formed to oppose a pumped-storage facility that would destroy Sunfish Pond and this attracts attention to Tocks Island Dam.

1967 Estimated Tocks Island Dam project costs increased to \$198 million. Time Magazine blasted President Johnson for unnecessary spending on Tocks Island Dam. Congress appropriated \$4 million for Tocks but the Army Corps budget was reduced. Justice William Douglas hikes to Sunfish Pond in support of its preservation.

1968 Estimated Tocks Island Dam project costs increased to \$203 million. Johnson began cutting his $\$ 4.6$ billion public works budget and grappled with imposing a 10 percent tax surcharge to help pay for the war. Inflation is out of control. There were 534,700 American troops in Vietnam. Congress appropriated only \$3.88 million to the Army Corps for Tocks, but that was cut an additional $\$ 1.83$ million by the Revenue and Expenditure Act. The project is way behind schedule.

1969 Estimated Tocks Island Dam project costs increased to \$214 million. Congress called for a new evaluation of the Tocks Island Dam Project and funding was again delayed. The General Accounting Office determined the dam's water supply benefit was underestimated while the recreational benefits of the dam and lake were over-estimated by the Army Corps. Only seven percent of the necessary land had been acquired for the Tocks Project and there were no construction contracts in place yet.

1970 President Nixon signs the National Environmental Policy Act. The Army Corps was then required to file an environmental impact statement on Tocks Island Dam. The Vietnam War scaled down, but Nixon cut his public works spending. 
1971 Tocks Dam is delayed because an incomplete environmental impact statement was submitted by the Army Corps. Save the Delaware Coalition was formed uniting dozens of organizations to fight the dam.

1972 New Jersey Governor Cahill demands conditions be met for NJ's continued support of the dam, including a reduction of anticipated annual park visitors from 10.5 million to 4 million, which greatly diminished mandatory project revenue benefits.

1974 Congress appropriates funds for an impartial new environmental impact study on the Tocks Island Dam and stipulates no money be spent on construction or land acquisition until this study is completed. New Jersey Governor Brendan Byrne has a team of environmentalists privately study the project.

1975 The estimated cost to build Tocks Island Dam increased to $\$ 400$ million and kept climbing. Delaware River Basin Commission votes 3 to 1 against construction of Tocks Island Dam. The War in Vietnam is over.

1978 A major section of the Delaware River becomes part of the National Wild and Scenic Rivers System, effectively blocking future dams.

1983 A Good Faith Agreement was reached by all parties to the US Supreme Court Case of 1931 and was adopted by the Delaware River Basin Commission.

1986 The Water Resource Development Act reforms and modernizes the Army Corps of Engineers. No more funds are spent on the dam.

1992 Congress de-authorizes Tocks Island Dam, but retains the option to revisit the issue if deemed necessary in the future. The Delaware River Basin Commission begins searching for alternate water sources.

2002 Congress officially de-authorizes Tocks Island Dam.

2008 A bill introduced to reauthorize a Delaware Water Gap National Recreation Area Citizens Advisory Commission through 2018 to periodically study the need for a dam on the Delaware is not passed.

Kathleen Duca is Director of Advancement Services, Research, and Prospect Management at Seton Hall University, where she has worked for more than 14 years. A former award-winning investigative journalist in both New Jersey and New York City, she studied philosophy, political science, and journalism at Georgetown and New York Universities. After putting her sons through college, she completed a Master's Degree in History with honors at Seton Hall. Kathleen is an avid reader, researcher, and writer, who loves American History. 